\title{
Renewable Energy Situation in Ghana and Future Prospect
}

\author{
Jinfeng Zhang, Daniel Adu, Yujian Fang, Eric Ofosu Antwi, and Solomon Oppong Kyekyeku
}

\begin{abstract}
Renewable energies represent a foundation to steer the energy system in the direction of sustainability and supply security in Ghana. The country has a huge undeveloped potential in the field of renewable energy. While Ghana has committed itself to universal electricity access by 2020 , the real challenge is the capacity to meet this goal and, most important, to ensure that supply is reliable and adequate. This paper outlines the state of current electricity demand, supply gap and CVVV V the major impediments to resolve the supply bottlenecks to meet demand. The paper again discusses current Renewable energy situation of Ghana and sustainable development strategy by the Year 2020. The current status and future prospects of Renewable Energy in Ghana are also addressed in the paper. Conclusion was drawn on the role of the Government and private investors on the Renewable Energy development in the Country.
\end{abstract}

Index Terms-Energy, renewable energies, hydropower, generation, energy demand.

\section{INTRODUCTION}

Electricity is a key determinant for economic growth in any emerging economy, however supply in most instances is always fraught with challenges. Ghana, one of the budding economies in Africa suffers a similar fate. Sustained demand growth of over $6 \%$ per year has strained the already overburdened electricity system. A major power crisis over the past 7 years is estimated to have reduced the country's GDP growth by $1 \%$. [1]. The Government through the support of international donors, has sought to strengthen the electricity sector in response to this problem. According to the World Bank, Africa lags behind globally when it comes to energy generation and supply. Access to electricity in Ghana is estimated at $75 \%$ this coupled with a generation capacity of 13,022 GWh. A cursory assessment will show that those with access to power typically consume relatively little and also face frequent outages as well as high prices of electricity. The

World Bank therefore recommends the implementation of policies that provide enabling conditions for private sector to increase investment in Africa's under-developed electricity transmission infrastructure. [2]) Ghana joined the White Paper for a Regional Policy' of the Economic Community of West African States (ECOWAS) which is geared towards

Manuscript received March 26, 2018; revised June 27, 2018.

Jinfeng Zhang, Daniel Adu, and Yujian Fang are with the National Research Center of Pumps, Jiangsu University, Zhenjiang 212013 China, (zhangjingfeng@ujs.edu.cn,_ adudaniel39@yahoo.com, 40588908@qq.com).

Eric Ofosu Antwi is with the University of Energy and Natural Resources, Sunyani Ghana (ericofosu2000@yahoo.com).

Solomon Oppong Kyekyeku is with the Ghana Immigration Service, Ghana (amajoy76@yahoo.com). increasing energy services access. One of the major aims of the policy was to ensure a $50 \%$ electricity access within the West African Sub-Region by 2015. [3]. About $90 \%$ of rural dwellers in Ghana depend on firewood and charcoal for cooking. [4], [5]. The Government of Ghana, with the help of international donors, has sought to strengthen the electricity sector in response to this challenge. The Government has outlined two key objectives for solving existing problems in the sector and allowing it to power sustainable, inclusive economic growth in the future as follows: (i) double installed generation capacity by 2015 ; and (ii) extend universal access to electricity by 2020 [6].

\section{A. The Current Electricity Situation in Ghana}

According to the World Bank Sustainable Energy for All Report, [7], the national household access to electricity in Ghana as at 2014 was $78.3 \%$. Ghana generates about $64 \%$ of its electrical power from hydro sources. Electricity is the dominant form of modern energy used in Ghana, accounting for about $65 \%$ of the energy used in the industrial and service sectors and about $35 \%$ in residential use. [8], [9], Energy Commission of Ghana (2014), identified some potential electricity consumption drivers such as industrial growth, petroleum up-stream as well as mid-stream activities, mining [10]. In total, Ghana's population is projected to increase from the 25 million estimated in 2010 to around 40 million by 2030 [11] Fig. 1 below shows Electricity

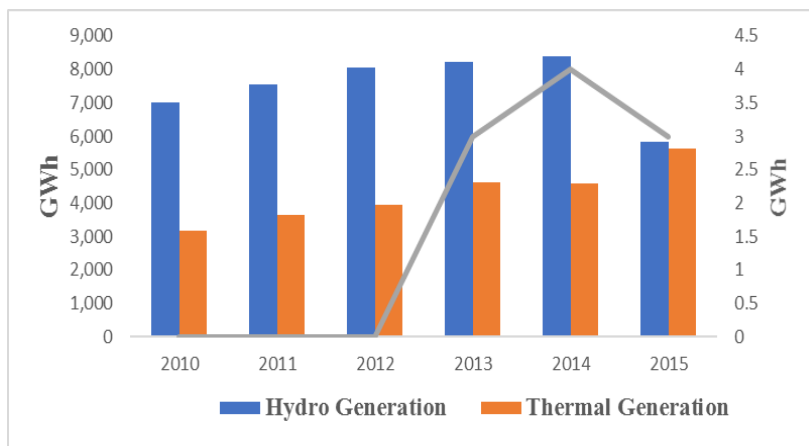

Fig. 1. Electricity generation in Ghana.

Generation in Ghana between 2010 to 2015 whereas Table I also shows the Electricity Installed capacity as at 2015.

\section{B. Electricity Demand and Supply Situation in Ghana}

There has been a rapid increase in electricity demand over the past decade in Ghana. the period between 2000 and 2013 saw a supply shortfall of $6340 \mathrm{GWh}$ in lieu of demand. Energy Commission. [13]. Industry accounted for about $45 \%$ of this shortfall and the rest being for residential and commercial sectors. [13]. It is expected that the relative market share of the consumer sector will change to $50 \%$ of the maximum demand for residential sector in 2020. [14]. 
Biomass consist mainly of wood fuel, and to lesser extent crop residues, accounts for half the Total Primary Energy Supply. Ghana's primary fuel for electricity generation has largely been hydro. The total electricity generation in 2015 was $11,492 \mathrm{GWh}$, with $50.86 \%$ being generation from hydropower, $49.1 \%$ from thermal power plants and the remaining $0.03 \%$ coming from other Renewables [10]. The generation from hydro resources has dropped from about $54 \%$ in the year 2013 to about $43.2 \%$ in 2016[15]. There has been a reduction in the industry sector electricity supply since 2000 which has actually abandoned the progress of the country [15] in the most recent energy crisis. The ongoing national power outages and load shedding in Gahan shows the disparity between supply and demand of electricity in the country. The total electricity generated for gross transmission in Ghana in 2014 was 13,071 GWh as against 12,927 GWh in 2013. Peak load for the supply to the country on the transmission grid2 was 1,970 MW about $10 \%$ above 2013 with total peak on the transmission grid3 also being 2,061 MW; around $6 \%$ over that of 2013. Ghana's corresponding peak demand (including suppressed demand) and total transmission system peak as at 2015 was between 1,980-2,300 MW. With The grid electricity available for supply being between 15,000 to 15,200 GWh [16]. Fig. 2 and Fig. 3 below shows the primary energy supply in Ghana, and energy consumed by consumers.

TABLE I: ELECTRICITY INSTALLED CAPACITY AS AT 2015 [12]

\begin{tabular}{|c|c|c|c|}
\hline \multicolumn{2}{|l|}{ PLANT } & Installed & Share $(\%)$ \\
\hline Hydro & $\begin{array}{l}\text { Akosombo } \\
\text { Bui } \\
\text { Kpong }\end{array}$ & $\begin{array}{l}1,020 \\
400 \\
160\end{array}$ & $\begin{array}{l}27.9 \\
10.9 \\
4.4\end{array}$ \\
\hline Thermal & $\begin{array}{l}\text { Takoradi } \\
\text { Power Company } \\
\text { (TAPCO) } \\
\text { Takoradi } \\
\text { International } \\
\text { Company } \\
\text { (TICO) } \\
\text { Sunon } \\
\text { Asogli Power } \\
\text { (Ghana) Limited } \\
\text { (SAPP) - IPP } \\
\text { Cenit } \\
\text { Energy Ltd } \\
\text { (CEL) - IPP } \\
\text { Tema } \\
\text { Thermal } 1 \\
\text { Power Plant } \\
\text { (TT1PP) } \\
\text { Tema } \\
\text { Thermal } \quad 2 \\
\text { Power Plant } \\
\text { (TT2PP) } \\
\text { Takoradi T3 } \\
\text { Mines } \\
\text { Reserve Plant } \\
\text { (MRP) } \\
\text { Kpone } \\
\text { Thermal Power } \\
\text { Plant (KTPP) } \\
\text { Karpowershi } \\
\text { p Ameri Plant } \\
\text { Ane }\end{array}$ & $\begin{array}{l}330 \\
330 \\
200 \\
\\
126 \\
110 \\
50 \\
132 \\
80 \\
220 \\
225 \\
250\end{array}$ & $\begin{array}{l}9.09 .0 \\
5.5 \\
3.4 \\
3.0 \\
1.4 \\
3.6 \\
2.2 \\
6.0 \\
6.2 \\
6.8\end{array}$ \\
\hline $\begin{array}{l}\text { Other } \\
\text { Renewables }\end{array}$ & $\begin{array}{l}\text { VRA Solar } \\
\text { BXC } \\
\text { Company }\end{array}$ & $\begin{array}{l}2.5 \\
20\end{array}$ & $\begin{array}{l}0.1 \\
0.5\end{array}$ \\
\hline
\end{tabular}

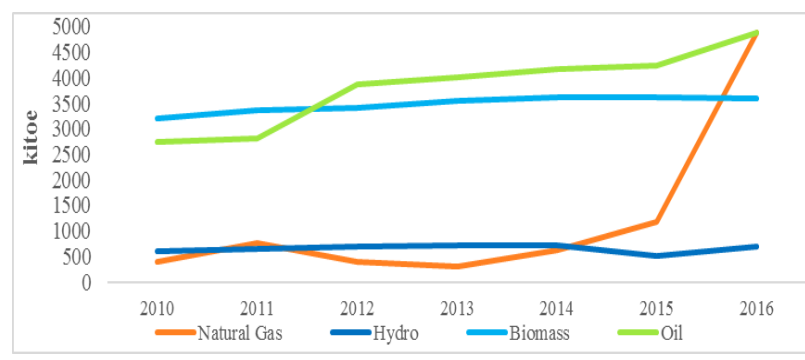

Fig. 2. Primary energy supply in Ghana [12].

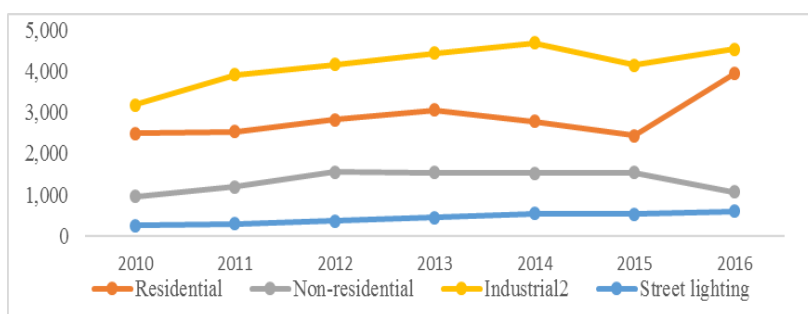

Fig. 3. Electricity consumed by customer/class [12].

According to Armah-Kofi Buah the formar Energy Minister of Ghana, the objective behind the Renewable Energy Act passed by the Ghanaian Parliament in November 2011 is to increase renewable energy such as solar, wind and thermal energy use in the country to $10 \%$ by the year 2020 . The Bill specifically empowers the Public Utility Regulatory Commission (PURC) to set the Feed-in-Tariffs (FITs) that determines the success or failure of the renewable energy sector. The Ministry of Energy has approximated over 6,000 solar systems with an installed capacity of 3.2MW have been installed in the country in 2015, mainly for off-grid applications. All technologies of solar energy which use global radiation to produce energy for instance PV's and water heaters would operate efficiently throughout the year in the country. Ghana's Public Utilities Regulatory Commission established feed-in tariff rates for electricity generated from renewable energy sources. The tariffs have been applying since 2013 and are technology specific (Table II). The duration of the support is 10 years for all projects, regardless of the technology [17].

TABLE II: FEED-IN TARIFF RATES FOR ELECTRICITY GENERATED FROM

\begin{tabular}{|c|c|c|}
\hline $\begin{array}{l}\text { Renewable energy } \\
\text { technology }\end{array}$ & $\begin{array}{l}\text { Duration of the } \\
\text { support }\end{array}$ & $\begin{array}{l}\text { Expressing of Tariffs } \\
(\mathrm{GHp} / \mathrm{kWh})\end{array}$ \\
\hline Wind & \multirow{6}{*}{ 10Years } & 32.1085 \\
\hline Solar & & 40.2100 \\
\hline Hydro $<10 \mathrm{MW}$ & & 26.5574 \\
\hline Hydro10MW > $100 \mathrm{MW}$ & & 22.7436 \\
\hline Landfill Gas & & 31.4696 \\
\hline Biomass & & 31.4696 \\
\hline
\end{tabular}

\section{Potential Alternative Sources of Energy Generation in Ghana}

Ghana generates electric power from hydropower, fossil-fuel (thermal energy), and renewable energy sources.

Electricity generation is one of the key factors in order to achieve the development in the Nation.

I. Solar PV (stand-alone and grid connected) and solar Lanterns

Ghana has adopted the GEDAP solar project to increase 
electricity access through solar photovoltaic systems in the rural and remote areas in the Country. This increase will help improve the quality of life as well as enhancing educational services, and provision of income-generating opportunities for the local People in the country. The solar lanterns and solar home systems are supplied by local companies with the view of driving local participation as well as innovation, to reach a point where the local industries can be in a position to produce these lanterns locally. Training has been given to quite a lot of technicians on the maintenance and installation of the systems. There has been an installation of around 16,500 systems made up of 8000 solar lanterns and 8500 solar home systems.IEA/ Feed-in tariff, IRENA Data Base [18], [19]. Ghana has the biggest and largest photovoltaic (PV) solar energy plant in Africa and the 4th biggest in the world thus Nzema project which is under construction. This $155 \mathrm{Mw}$ plant will be able to provide over 100,000 homes in the Country with electricity to increase electricity generating capacity in the Country by $6 \%$. When fully in operation, [19]. The BXC Solar Plant in Ghana's Central Region is the largest functioning solar farm in West Africa. It started operation in February 2016 and owned by a Chinese company. after two years of construction, it produces 20MW of power, largely contributing to Ghana's ambitious plan to reach $10 \%$ renewables milestone by 2020 . The panels will help the country change to cleaner power. The country's transition to solar has started slowly, making the objective of a 10 percent slice of energy resources coming from renewables by 2020 challenging [20].

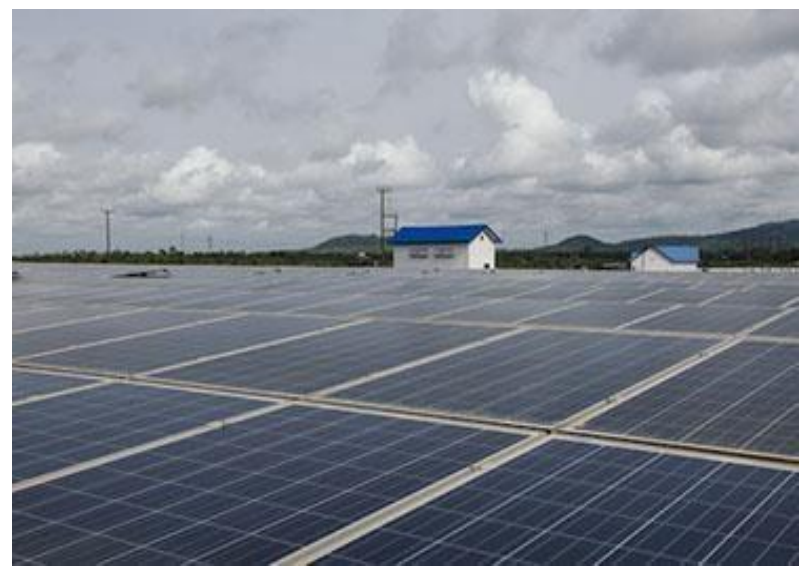

Fig. 4. The BXC solar plant in Ghana.

\section{BIO ENERGY}

Mechanisms have been put in place to attract biomass and bio-energy sector investment. To boost rural energy development as well as create jobs for the country [21]. Ghana's huge arable and degraded mass land has the potential for cultivating crops and plants which may perhaps be converted into a wide range of solid and liquid bio-fuels, since alternative transportation fuels development can assist in safeguarding and expanding

Ghana's future energy supplies. Main investments in the bio-energy subsector existed in the areas of production, are transportation, storage, distribution, sale, marketing and exportation. Biomass is the main energy resource in Ghana in terms of production and consumption, with the two-primary consumed bio-fuels being ethanol and biodiesel [21].
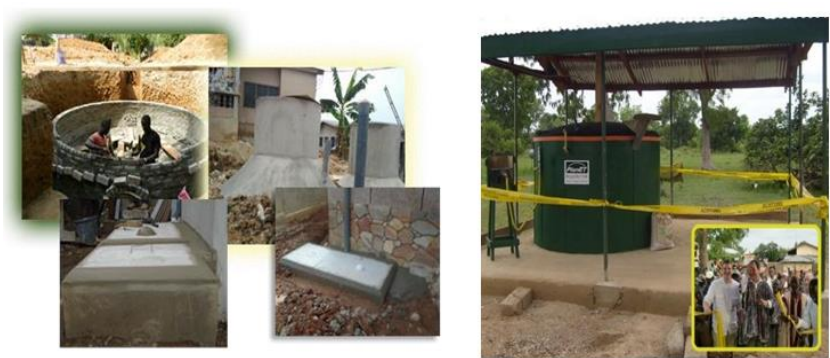

Fig. 5. Biogas plants in Ghana.

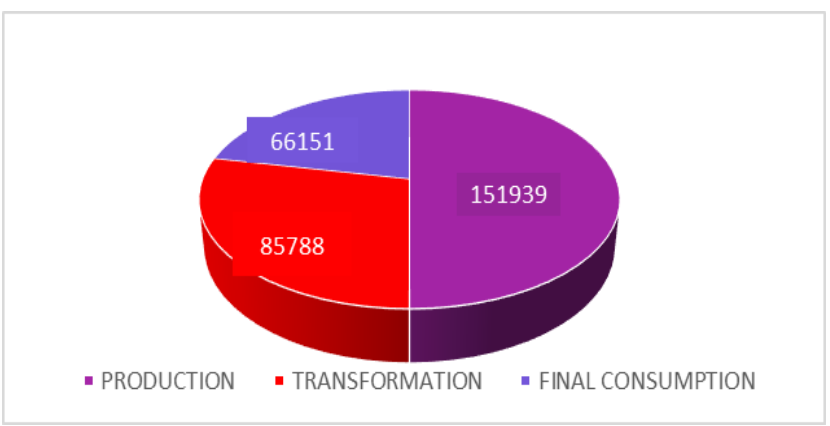

Fig. 6. Biofuels use in Ghana [12].

\section{WIND RESOURCE POTENTIAL}

Besides hydropower and solar energy, wind power is also another renewable energy source that produces electricity in Ghana. Wind energy have a good moderate potential estimated to be about 406MW Suitable for water pumping, Grid connection and off grid applications along the eastern costal belt of Ghana with a speed of over $6 \mathrm{~m} / \mathrm{s}$ estimated at $50 \mathrm{~m}$. there are Class 4-6 wind resources found on the highest wind areas like Nkwanta, the Accra Plains, Kwahu Plains and Gambaga mountains in Ghana. These available wind energy resources can provide estimated minimum energy of around $500-600 \mathrm{GWh} /$ year. there is a potential of wind energy to greatly support Ghana's energy sector.

$5 \%$ of wind energy could be surely reached in terms of installed capacity. [22].

\section{HYDROPOWER}

The Akosombo Dam has been Ghana's main source of energy since the 1960s, however, due to recent droughts, it has been operating at minimum capacity. But today, the six turbines of the dam are struggling to generate $67 \%$ of power to the country as it used to in in previous years. over the past 57 years since Akosombo was built, electricity demand in Ghana has witnessed a steeply growth of over $300 \%$, reaching a peak of $1126.82 \mathrm{GWh}$ in 2015 [23]. Ghana's total installed capacity currently stands at 2,936 MW, just over half of which is provided by hydropower which has the highest electricity supply capacity in Ghana with a total of 1,580 MW installed capacity. This contribution is accounted for by three stations such as Akosombo (1,020 MW), Kpong (160 MW) and Bui (400 MW). Development of smaller hydropower projects in Ghana is still a challenging issue, as a result of lack of a regulatory and legal framework for renewable energy, and limited economic incentives to attract 
investors. The actions to encourage and accelerate hydropower development in Ghana by the government is to help meet the increasing electricity demand of the country [24].

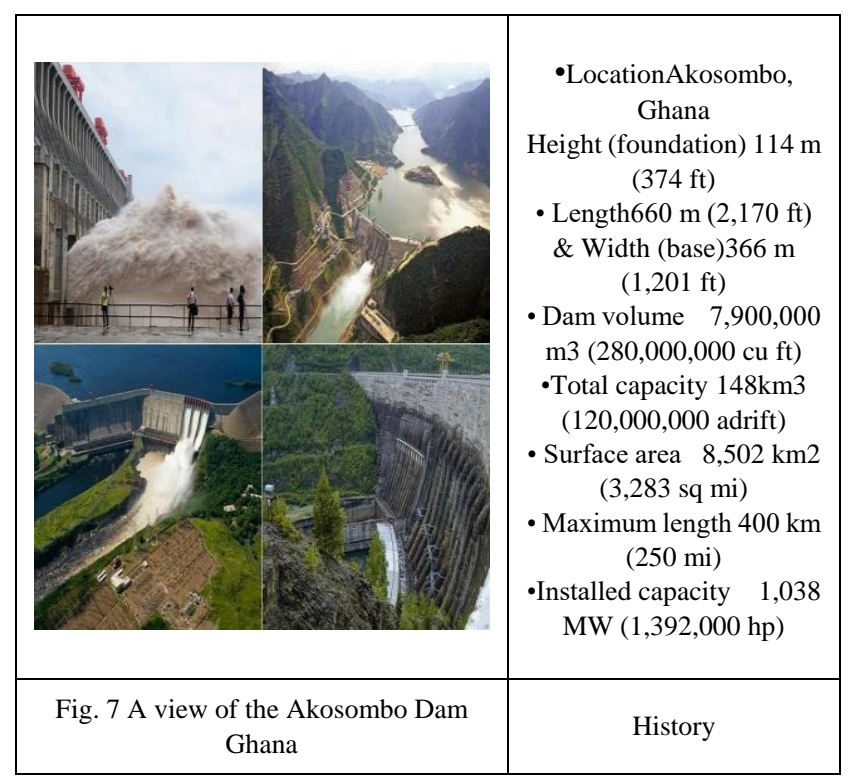

\section{CONCLUSION}

Several African countries started energy sector reform in order to supply energy to the rural communities who are not connected to the main grid and also provide affordability, clean, safe and efficient fuels to the people. Quite a lot of policy mechanisms and institutions have over the years been on board to help deliver a better energy access in Ghana. Biomass in the form of wood fuel HAS been the main fuel source in in Ghana for cooking and heating. Firewood and charcoal has been contributing substantially in the total energy consumption of Ghana. This is a major source of worry taking into consideration its adverse effects on Human health as well as deforestation and the problems associated with indoor pollution from its use. The energy sector in Ghana has not seen much contribution from Renewable energy. solar PV Gains when compared to the potential country, have been modest. Wind energy and small hydro resources have not been exploited fully and biofuel programs are still in the feedstock stage. Ghana has great potential for several different industries in renewable energy. There is also a huge undeveloped potential in wind, solar and Small

Hydropower. THE Government of Ghana needs to involve the private investors to help harness these resources

\section{ACKNOWLEDGEMENTS}

We thank National Natural Science Foundation of China form their financial support. Mrs. Joyce Adu and Sam Nana Adu-Kumi for their Advice and encouragement

\section{REFERENCES}

[1] World Ban, Energizing Economic Growth: Making the Power and Petroleum Sectors Rise to the Challenge, 2013.

[2] World Bank Botswana, How to Boost Private Sector Investment in Africa's Electricity Infrastructure Glob Server, 2017.

[3] ECOWAS, White paper for a Regional Policy Geared towards Increasing Access to Energy Services for Rural and Peri-urban
Populations in Order to Achieve the Millennium Development Goals, Supported by UNDP and French Ministry of Foreign Affairs, 2005.

[4] Ghana Statistical Service, Ghana 2003 Core Welfare Indicators Questionnaire (CWIQ II) Survey Report, Accra, Ghana: Ghana Statistical Service, 2005.

[5] UNDP Ghana, Liquefied Petroleum Gas (LPG) Substitution for Wood Fuel in Ghana Opportunities and Challenges, Accra, 2004.

[6] National Energy Policy, Ghanaian Ministry of Energy, February 2010.

[7] World Bank, Access to Electricity (\% of Population), World Bank, Sustainable Energy for All (SE4ALL) Database from the SE4ALL Global Tracking Framework Led Jointly by the World Bank, 2013, Access 26/06/2017.

[8] J. Meng, (2004). Ghana's development, miracle or mirage? [Online] Available: http://www.joycemeng.com/writings/ghana.pdf

[9] IRENA, "Renewable energy technologies: cost analysis series," IRENA, vol. 1, Issue 3/5, 2012.

[10] Ghana Energy Commission, Energy (Supply and Demand) Outlook for Ghana, Final Report, 2014.

[11] M. S. Alam, Economic growth with energy. Munich Personal RePEc Archive (MPRA), 2006.

[12] GEC, National Energy Statistics 2016 Strategic Planning and Policy Directorate, 2017.

[13] GEC, "National energy statistics 2000-2013," Energy Commission, 2013

[14] PSEC, Ghana Wholesale Power Reliability Assessment, Final Report Power Systems Energy Consulting, 2010.

[15] GEC, "Energy (supply and demand) outlook for Ghana," Ghana Energy Commission, 2011.

[16] GEC, Ghana Energy (Supply and Demand) Outlook for Ghana, 2015.

[17] IEA/ IRENA, Feed-in Tariff for Electricity Generated from Renewable Energy Sources, IRENA joint Policies and Measures Data Base 2017, 2017.

[18] IEA, National Electrification Scheme, IEA/ IRENA joint Policies and Measures Data Base 2017, 2017.

[19] J. C. Ahiekpor, Solar Lantern Projects in Ghana: An Overview. Final Draft Report Prepared for the Netherlands Development Organization (SNV), 2013

[20] Adam Vaughan, (2012). Africa's largest solar power plant to be builtinGhana. The Guardian. [Online]. Available: https://www.theguardian.om/environment/2012/dec/04/africa-lagrestsolar-power-plant-ghana

[21] The Ghana Energy Access (GhEA), (2017). Toolkit a renewable energy and energy access information system. [Online]. Available: http://ghea.energycom.gov.gh/database/index.php\#

[22] Renewable and Shao Hai Jun, (2012). Ghana to attract investment into bio-energy sector. [Online]. Available: http://www.energymin.gov.gh/?page_id=205 energymin.gov.gh, http://www.china.org.cn/world/Off_the_Wire/20

[23] Renewable Energy, (2013). What is Ghana's wind power potential [Online]. Available: https://web.archive.org/web/20130407152744/

[24] C. Caterina, S. Marisa, and T. Kevin, (2016). The electricity outages leaving Ghanainthedark. [Online]. Available: https://interactive.aljazeera.com/aje/2016/ghana-electricity-outage dumsor/index.html\#energy-generation

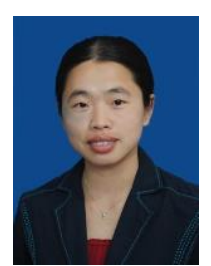

Jinfeng Zhang, associate professor of fluid machinery engineering technology research center in Jiangsu University. doctor of technical science, master tutor. She is the vice director of fluid machinery engineering technology research center of Jiangsu University, the deputy director of the national water pump and system engineering technology research center and the deputy director of the Institute of fluid engineering equipment technology in Jiangsu industrial technology research institute alike. From 2013 to 2014, she took a refresher course in Karlsruhe University as a visiting scholar.

Prof. Dr. Zhang long been engaged in the design and research of fluid machinery products, with the numerical simulation of flow field in centrifugal pump and modern testing technology being her current research directions. She presided over the national natural science fund and the Jiangsu province natural science fund and has also participated in 6 research tasks such as the national "863" project, the national natural science foundation, the research work of the national science and technology support program. She was honored with the national science and technology progress award, scientific and technological progress of colleges and universities for two times, the second prize of Jiangsu scientific and technological progress, the third prize of China machinery industry science and technology award for two times and china coal industry association science and technology award 
besides, she has published more than 18 papers, including 1 papers indexed by SCI, 10 EI retrieval articles, 2 authorized invention patents, 1 patents, and 1 published monographs.

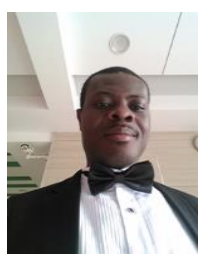

Daniel Adu is a PhD student at the National research Centre of Pumps, Jiangsu University, China offering Fluid Machinery Engineering in the research area of small hydropower development in Africa. Pump as turbine for small hydropower generation master Daniel had his expertise in evaluation and passion in improving electricity situation in Africa. He has done a lot of research into how this electricity crisis in Africa especially sub-Saharan Africa can be solved and found small hydropower as one of the best ways to solve these challenges due to its enormous potential in the continent

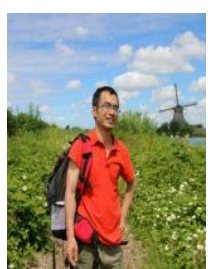

Yujian Fang is a PhD student at the National research Centre of Pumps, Jiangsu University, China offering fluid machinery engineering in the research area of small hydropower development.

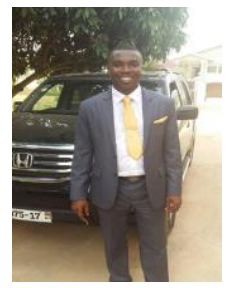

Eric Antwi Ofosu holds BSc and MPhil in civil engineering from the Kwame Nkrumah University of Science and Technology and a PhD in integrated water resources management from the Technical University of Delft and UNESCO-IHE.

Dr. Eric Antwi Ofosu has expertise in hydropower engineering, water resources management and irrigation development and is currently a senior lecturer at the Department of Energy and Environmental Engineering, University of Energy and Natural Resources.

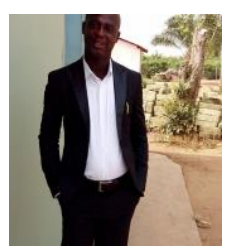

Solomon Oppong Kyekyeku holds BSc and MPhil in sociology from University of Cape Coast has expertise water resources management and irrigation development and is currently a par time lecturer KNUST. 